\title{
Fruit tree model for uptake of organic compounds from soil and air
}

\author{
Trapp, Stefan
}

Published in:

SAR - QSAR in Environmental Research

Link to article, DOI:

10.1080/10629360701303693

Publication date:

2007

Link back to DTU Orbit

Citation (APA):

Trapp, S. (2007). Fruit tree model for uptake of organic compounds from soil and air. SAR - QSAR in Environmental Research, 18, 367-387. https://doi.org/10.1080/10629360701303693

\section{General rights}

Copyright and moral rights for the publications made accessible in the public portal are retained by the authors and/or other copyright owners and it is a condition of accessing publications that users recognise and abide by the legal requirements associated with these rights.

- Users may download and print one copy of any publication from the public portal for the purpose of private study or research.

- You may not further distribute the material or use it for any profit-making activity or commercial gain

- You may freely distribute the URL identifying the publication in the public portal

If you believe that this document breaches copyright please contact us providing details, and we will remove access to the work immediately and investigate your claim 
SAR and QSAR in Environmental Research 2007, 18, 367-387.

Fruit Tree model for uptake of organic compounds from soil and air

\author{
STEFAN TRAPP \\ Institute of Environment \& Resources \\ Technical University of Denmark \\ DK-2800 Kongens Lyngby, Denmark
}

E-mail stt@er.dtu.dk, Tel +45 4525 1622, Fax +45 45932850

Running title: Fruit tree model 
Abstract. The current European risk assessment for chemicals considers only tap water, while in reality other beverages play an important role. A good part of beverages are made from fruits, for example apple juice and vine. A mathematical model was developed to predict uptake of neutral organic chemicals from soil and air into fruits. The new fruit tree model considers eight compartments, i.e. two soil compartments, fine roots, thick roots, stem, leaves, fruits and air. Chemical equilibrium, advective transport in xylem and phloem, diffusive exchange to soil and air and growth dilution are the main processes. The parameterization is for a square-meter of an apple orchard. The model predicts that polar, non-volatile compounds will effectively be transported from soil to fruits, while lipophilic compounds will preferably accumulate from air into fruits. Results from various experiments show no disagreement with the model predictions.

Key words: apple; contamination; fruit tree; model; risk; 


\section{Introduction}

Current exposure and risk assessment for chemicals in the EU, as described in the Technical Guidance Documents TGD [1] and implemented in the European Union System for the Evaluation of Substances EUSES [2] considers drinking of humans by consumption of $2 \mathrm{~L}$ water per day. This does not reflect our daily reality. For example, the consumption pattern of the Bavarian population was studied recently [3]. In mass units (g/day), tap water is the major consume, followed by beer (male population), bread, juice and other beverages (Figure 1). Among the top 12 of consumed food items are 5 made of fruits (beer, bread, juice, some of the vegetables and wine). The majority of consumption is clearly beverages. If these are summed up, they make up $74 \%$ (mass) of daily consumption, hereof $35 \%$ tap water and $39 \%$ other beverages (coffee and tea not counted). Maximum residue limits (MRLs) in drinking water are available for a long list of pollutants [4], including heavy metals, inorganic and organic chemicals. For pesticides in drinking water, a common MRL was set to $0.0001 \mathrm{mg} \mathrm{L}^{-1}$ [5]. Legal standards for environmental chemicals in fruits, juice or wine have rarely been set. Only for pesticides, MRLs are available for fruits. However, they are orders of amounts higher than for tap water. MRLs for processed fruits, such as beverages like juice or wine, were not set. This is despite the fact that pesticide residues in fruit and vegetables are EU citizen's major food concern [6]. During the latest German national study on pesticides in food [7], 15491 food samples were taken and measured on up to 634 pesticides (in total 2122267 analysis). Pesticide residues were found in 60\% of samples, hereof $7.4 \%$ of samples were above the maximum residue level (MRL). For wine grapes, in total 1068 samples were taken. Hereof, $224(21 \%)$ were without detectable pesticide residues, 138 (12.9\%) were with pesticides above MRL, and 64.5\% of the samples contained more than one pesticide residue. For apples, the respective 
numbers were 794 samples, hereof 217 (27.3\%) without detectable pesticide residues, $43(5.4 \%)$ with pesticides above MRL and $38.4 \%$ with multiple pesticide residues.

The exposure of the European population to chemicals in fruits is thus of concern and deserves further attention. This work will establish a mathematical model to predict the uptake pathways and the accumulation of chemicals from soil and/or air into fruits. Direct application (e.g. as pesticide spray), is not considered here.

[Please place here Figure 1]

\section{Methods}

\subsection{Model development}

The mathematical model for uptake of contaminants from air and soil into fruits is based on earlier model approaches [8-15]. The structure of the model is shown in Figure 2. It consists of eight compartments (soil 1, soil 2, fine roots, thick roots, stem, leaves, fruit, air). For four compartments (thick roots, stem, leaves, fruits), the mass balances were formulated as differential equations. Transport processes are advection (with xylem and phloem sap) and diffusive loss or gain. Dilution by growth and metabolism can be considered.

[Please place here Figure 2]

2.1.1 Chemical equilibrium between fine roots and soil. The natural bulk soil consists of soil matrix, soil solution and soil gas. This is considered in the calculation of the chemical equilibrium between soil water and wet bulk soil $\mathrm{K}_{\mathrm{WS}}$. 


$$
\frac{C_{W}}{C_{S}}=K_{W S}=\frac{\rho_{\text {wet }}}{O C \times K_{O C} \times \rho_{\text {dry }}+W_{S}+G_{S} \times K_{A W}}\left(\mathrm{~kg} \mathrm{~L}^{-1}\right)
$$

where $C_{W}\left(\mathrm{~m} \mathrm{~L}^{-1}\right)$ is the concentration of the chemical in soil water and $\mathrm{C}_{\mathrm{S}}\left(\mathrm{mg} \mathrm{kg}^{-1}\right)$ in wet bulk soil; $\rho$ is the density of wet or dry soil $\left(\mathrm{kg} \mathrm{L}^{-1}\right)$, OC is the fraction of organic carbon $\left(\mathrm{kg} \mathrm{kg}^{-1}\right), \rho_{\text {dry }}$ is the density of the dry soil, and $\mathrm{W}_{\mathrm{S}}$ and $\mathrm{G}_{\mathrm{S}}$ are the volume fractions of water and gas in soil $\left(\mathrm{L} \mathrm{L}^{-1}\right)$. $\mathrm{K}_{\mathrm{AW}}$ is the partition coefficient between air and water. The air phase can usually be neglected, except for high $\mathrm{K}_{\mathrm{Aw}} . \mathrm{K}_{\mathrm{OC}}\left(\mathrm{L} \mathrm{kg}^{-1}\right)$ is the partition coefficient between organic carbon and water and can be estimated from the octanol-water partition coefficient $\mathrm{K}_{\mathrm{OW}}[1]$ :

$\log K_{O C}=0.81 \times \log K_{\text {OW }}+0.1$

Fine roots. The very high surface to volume ratio of fine roots is favoring diffusive transfer. It is thus assumed that fine roots are in chemical equilibrium with the surrounding soil. Briggs et al. [16] mazerated barley roots and measured the concentration ratio to solution for chemicals with different $\mathrm{K}_{\mathrm{OW}}$. They expressed their result as "root concentration factor" $\mathrm{RCF}\left(\mathrm{L} \mathrm{kg}^{-1}\right)$ :

$R C F=\frac{\text { concentration in roots }(\mathrm{mg} / \mathrm{kg})}{\text { concentration in water }(\mathrm{mg} / \mathrm{L})}$

The fit curve between RCF and $\mathrm{K}_{\mathrm{Ow}}$ gave

$\log (R C F-0.82)=0.77 \times \log K_{\text {OW }}-1.52$ 
or $R C F=0.82+0.03 \times K_{O W}{ }^{0.77}$

The RCF can be considered as chemical equilibrium $\mathrm{K}_{\mathrm{RW}}\left(\mathrm{L} \mathrm{kg}^{-1}\right)$ between root concentration $C_{R}$ (mg per kg fresh weight) and water $C_{W}\left(m g L^{-1}\right)$. The partitioning is due to sorption to root lipids and dissolution into the aqueous solution of root cells:

$K_{R W}=W_{R}+L_{R} \times a \times K_{O W}{ }^{b}$

where $\mathrm{W}_{\mathrm{R}}\left(\mathrm{L} \mathrm{kg}^{-1}\right)$ and $\mathrm{L}_{\mathrm{R}}\left(\mathrm{kg} \mathrm{kg}^{-1}\right)$ are water and lipid content of the root, 'b' for roots is 0.77 and ' $^{\prime} \mathrm{a}=1 / \rho_{\text {Octanol }}=1.22 \mathrm{~L} \mathrm{~kg}^{-1}$. The concentration in fine roots, $\mathrm{C}_{\mathrm{R} 1}$, is thus

$C_{R 1}=C_{S 1} \times K_{R 1 S 1}=C_{S 1} \times K_{R 1 W} \times K_{W S 1}$

where the index 1 denotes the lowest compartment (fine root R1 and surrounding soil S1). The concentration in the xylem (aqueous solution) leaving from fine root and entering thicker parts of the root, $C_{X y 1}\left(\mathrm{mg} \mathrm{L}^{-1}\right)$, would thus be identical to the concentration in soil water:

$C_{X y 1}=\frac{C_{R 1}}{K_{R 1 W}}=C_{W 1}$

2.1.2 Thick roots. For thick roots, index R2, a dynamic flux model is applied [13].

The change of chemical mass in roots is + flux in with water - flux out with water metabolism. 
$\frac{d m_{R 2}}{d t}=+C_{X y 1} \times Q-C_{X y 2} \times Q-k_{m} \times m_{R 2}$

where $m_{R 2}$ is the mass of chemical in thick roots, $Q$ is the transpiration stream $\left(\mathrm{L} \mathrm{d}^{-1}\right)$ and $C_{X y 2}$ is the concentration in the xylem out of roots 2 (thick roots) $=\mathrm{C}_{\mathrm{R} 2} / \mathrm{K}_{\mathrm{R} 2 \mathrm{~W}}$; $\mathrm{k}_{\mathrm{m}}$ is a first-order metabolism rate $\left(\mathrm{d}^{-1}\right)$. Diffusive uptake from/to soil is added by applying Fick's 1st Law of diffusion:

$\frac{d m_{R 2}}{d t}=Q \times C_{W 1}-Q \times \frac{C_{R 2}}{K_{R 2 W}}+1000 \times A_{R 2} \times P_{R 2} \times C_{W 2}-1000 \times A_{R 2} \times P_{R 2} \times \frac{C_{R 2}}{K_{R 2 W}}-k_{m} \times m_{R 2}$

where $\mathrm{A}$ is the surface area $\left(\mathrm{m}^{2}\right)$ and $\mathrm{P}$ is the permeability $\left(\mathrm{m} \mathrm{d}^{-1}\right)$ of the root. The factor thousand is a unit conversion factor $\left(\mathrm{m}^{3}\right.$ to $\left.\mathrm{L}\right)$.

From mass to concentration. The chemicals' concentration $\mathrm{C}\left(\mathrm{mg} \mathrm{kg}^{-1}\right)$ is derived from its mass $\mathrm{m}(\mathrm{mg})$ by dividing through the mass of the medium $\mathrm{M}(\mathrm{kg})$.

$C=m / M$

It follows that $d(C M) / d t=d m / d t$. The difficulty of non-constant plant mass $\mathrm{M}$ due to growth can be handled in the following way: If growth is exponential, and the ratio of transpiration to plant mass $Q / M$ is constant, the dilution by exponential growth can be considered by adding the first-order growth rate $k_{R}\left(\mathrm{~d}^{-1}\right)$ to the first-order loss rate, $k=$ $k_{R}+k_{m}$. This gives the differential equation for the change of concentration in thick roots $\mathrm{R} 2$ : 
$\frac{d C_{R 2}}{d t}=\frac{Q}{M_{R 2}} \times C_{W 1}-\frac{Q}{K_{R 2 W} \times M_{R 2}} \times C_{R 2}+\frac{1000 \times A_{R 2} \times P_{R 2}}{M_{R 2}} \times C_{W 2}-\frac{1000 \times A_{R 2} \times P_{R 2}}{K_{R 2 W} \times M_{R 2}} \times C_{R 2}-k \times C_{R 2}$

Setting $d C_{R} / d t=0$ gives the steady-state solution for the concentration in thick roots $C_{R 2}$ :

$C_{R 2}=\frac{C_{W 1} \times Q+1000 \times A_{R 2} \times P_{R 2} \times C_{S 2} \times K_{W S 2}}{\frac{Q+1000 \times A_{R 2} \times P_{R 2}}{K_{R 2 W}}+k \times M_{R 2}}$

$\mathrm{S} 2$ is the index for the soil surrounding the thick roots.

The equations for calculating permeability $\mathrm{P}$ for roots are described in detail in appendix 1.

2.1.3 Stem. The transpiration water is translocated upwards in the xylem. Dissolved chemicals can flow with the water and enter the stem. The chemical can flow further with the water; or absorb to the stem; it can be metabolised or volatilize into air; but a chemical can also be taken up from air, if present there. The whole system is similar to a river, with water, sediment and air. Therefore, the same approach as for a river is used, namely the model RIVER in Cemos [11]. The basic equation is common to many river models, e.g., the BOD term in the well-known old Streeter-Phelps model:

$$
\frac{d C}{d t}=-k t
$$

with the common solution 
$C(t)=C(0) \times e^{-k t}$

The time coordinate $\mathrm{t}(\mathrm{d})$ is transferred to stem height $\mathrm{z}(\mathrm{m})$ via $\mathrm{t}=\mathrm{z} / \mathrm{u}$, where $\mathrm{u}$ is the flow velocity $\left(\mathrm{m} \mathrm{d}^{-1}\right)$. Interestingly, this solution is identical to the solution provided by Ma and Burken [17]. Only flow velocity of the chemical is treated differently, and uptake from air can be considered here (see below).

The initial concentration in xylem, when it enters the stem, is identical to the outflow concentration from thick root $\mathrm{C}_{\mathrm{Xy2}}$. The concentration in stem at height $\mathrm{z}=0$ is assumed to be in chemical equilibrium with that:

$C_{\text {Stem }}(0)=C_{X y 2} \times K_{\text {StemWater }}$

where $\mathrm{K}$ is the partition coefficient. The concentration at height $\mathrm{z}$ is

$C_{\text {Stem }}(\mathrm{z})=C_{\text {Stem }}(0) \times e^{-k z / u_{c}}$

where $u_{c}$ is the flow velocity of the chemical, and $\mathrm{k}$ is the sum of the loss rates (metabolism and volatilization) plus the rate of growth dilution. The concentration of the chemical in the xylem, when it leaves stem at height $h, \mathrm{C}_{\mathrm{Xy} 3}$, is

$$
C_{X y 3}=\frac{C_{\text {stem }}(h)}{K_{\text {StemWater }}}
$$

The loss rate via volatilization from stem is 
$k_{V}=\frac{A_{S t}}{M_{\text {Stem }}} \times P \times \rho_{\text {Stem }}$

or, easier, because for a cylinder of height $h$ and radius $r$, volume $V=M / \rho=\pi r^{2} h$ and outside area $\mathrm{A}=2 \pi \mathrm{rh}$ :

$k_{V}=\frac{2 P}{r}$

The flow velocity of the chemical $u_{C}$ is the flow velocity of water $u_{W}$ multiplied with the fraction of chemical present in water, $u_{C}=u_{W} x f_{W}$, where $f_{W}=W_{\text {Stem }} / K_{\text {StemWater }}$.

Partition coefficient. Different from herbs, trees have a big wood compartment. The ratio between a chemical's concentration in wood and its concentration in the water was named "K $\mathrm{K}_{\text {Wood" }}$ (mg chemical per g dry wood to mg chemical per mL water). Log $\mathrm{K}_{\text {Wood }}$ was significantly correlated to the $\log \mathrm{K}_{\mathrm{OW}}$ of the chemical and the following regressions were established [12]:

$$
\begin{array}{ll}
\log K_{\text {Wood }}=-0.27+0.632 \times \log K_{\text {OW }} & \text { (oak) } \\
\log K_{\text {Wood }}=-0.28+0.668 \times \log K_{\text {OW }} & \text { (willow) }
\end{array}
$$

The concentration ratio in chemical equilibrium between stem (wood + water + air) and water (such as xylem sap) is thus

$$
K_{\text {StemWater }}=\frac{\rho_{\text {dry }}}{\rho_{\text {wet }}} K_{\text {wood }}+W_{S t}+G_{S t} \times K_{A W}
$$


where $\mathrm{W}$ and $\mathrm{G}$ are the fractions of water and gas in the stem $\left(\mathrm{L} \mathrm{kg}^{-1}\right)$.

Input from air. While the xylem flow moves upwards, chemicals from air can enter the stem and the xylem. This is treated in the differential equation as a constant input I (mg $\left.\mathrm{kg}^{-1} \mathrm{~d}^{-1}\right)$

$I=\frac{A \times P}{V \times K_{A W} \times 1000} \times K_{\text {StemWater }} \times C_{\text {Air }}$

where 1000 is a conversion factor for $C_{\text {Air }}$ from $\mathrm{mg} \mathrm{m}^{-3}$ (the usual unit for air) to $\mathrm{mg} \mathrm{L}^{-1}$ (the usual unit for water) ; or, easier, replacing $\mathrm{A} / \mathrm{V}$

$I=\frac{2 \times P}{r \times K_{A W} \times 1000} \times K_{\text {StemWater }} \times C_{\text {Air }}$

Adding input from air to the mass balance yields

$\frac{d C}{d t}=-k C+I$

with the common solution

$C(z)=C(0) \times e^{-k z / u}+\frac{I}{k} \times\left(1-e^{-k z / u}\right)$

This means that due to input from air, the concentration can increase along the stem from $\mathrm{z}=0$ to $\mathrm{z}=\mathrm{h}$ (height). 
Sapwood and flow velocity. Measured flow velocities of water in trees range from 0.4 $\mathrm{m} \mathrm{h}^{-1}$ to $44 \mathrm{~m} \mathrm{~h}^{-1}$ [18]. This is far above the filter velocity, which would be yielded from dividing transpired water $\mathrm{Q}$ by stem cross-area $\mathrm{A}_{\text {cross }}$. The reason is that the water flows only in the outer rings of the tree (the "sapwood"). The volume of the sapwood can thus be calculated by comparing the measured water flow velocity $\mathrm{u}_{\mathrm{W}}$ with the filter velocity.

Filter velocity $=u_{F}=\frac{Q}{A_{\text {cross }} \times W_{S t}}$

The cross area of the sapwood ring is

$$
A_{\text {Ring }}=\pi \times\left(R^{2}-r^{2}\right)
$$

where $\mathrm{R}$ is the outer stem radius and $\mathrm{r}$ the inner radius of the sapwood. For $\mathrm{A}_{\text {Ring }} / \mathrm{A}_{\text {cross }}=$ $\mathrm{u}_{\text {meas }} / \mathrm{u}_{\mathrm{F}}$ follows:

$r=\sqrt{R^{2}-R^{2} \times \frac{u_{F}}{u_{\text {meas }}}}$

and $\mathrm{R}-\mathrm{r}$ is the thickness of the sapwood.

Permeability for exchange between stem and air. The model assumes a two-sidesresistance model, with one resistance being the wood and bark of the tree, the other being a stagnant air layer around the bark. The permeability of the stem is calculated analogously to the root. $K_{\text {StemWater }}$ is used instead of $K_{R W}, W_{S t}$ and $G_{S t}$ replace $W_{R}$ and $\mathrm{G}_{\mathrm{R}}$. The diffusion path-length is taken as $\mathrm{R}-\mathrm{r}+\mathrm{d}_{\mathrm{Bark}}$, where $\mathrm{d}_{\mathrm{Bark}}$ is the thickness of the bark (default $0.01 \mathrm{~m}$ ). The permeability of the air layer is calculated as 
$P_{\text {Air }}=\frac{D_{G}}{d x}$ where $\mathrm{dx}$ is the thickness of the stagnant air layer, by default $0.01 \mathrm{~m}$.

The total permeability follows from Kirchhoff's Law:

$$
P_{\text {total }}=\frac{1}{\frac{1}{P_{\text {Stem }}}+\frac{1}{P_{\text {Air }} \times K_{A W}}}
$$

2.1.4 Leaves. The leaf compartment is treated as in the model PlantX [19], with the steady-state solution as in [9]. It gives the same result, if the input data are identical. Input is from stem via the xylem and from air (as before), loss is by metabolism and to air. The change of mass in leaves $=+$ translocation from stem + uptake from air - loss to air - metabolism

$$
\frac{d m_{L}}{d t}=+Q_{L} \times C_{X y 3}+\frac{P_{L} \times A_{L}}{K_{A W}} \times C_{A i r}-\frac{1000 \times P_{L} \times A_{L}}{K_{L W}} \times C_{L}-k_{m} \times M_{L}
$$

where $\mathrm{L}$ is the index for leaves. $\mathrm{Q}_{\mathrm{L}}$ is the part of the transpiration stream that flows into leaves. $K_{L W}=W_{L}+L_{L} \times a \times K_{O W}{ }^{b}$ with $\mathrm{a}=1.22$ and $\mathrm{b}=0.95$ for leaves. For the concentration follows (including growth with $\mathrm{k}_{\mathrm{L}}=\mathrm{k}_{\mathrm{m}}+\mathrm{k}_{\mathrm{g}}$ ):

$$
\frac{d C_{L}}{d t}=+\frac{Q_{L}}{M_{L}} \times C_{X y 3}+\frac{P_{L} \times A_{L}}{K_{A W} \times M_{L}} \times C_{A i r}-\frac{1000 \times P_{L} \times A_{L}}{K_{L W} \times M_{L}} \times C_{L}-k_{L} \times C_{L}
$$

In steady-state: 


$$
C_{L}=\frac{Q_{L} \times C_{X y 3}+A_{L} \times P_{L} \times \frac{C_{A}}{K_{A W}}}{\frac{A_{L} \times P_{L} \times 1000}{K_{L W}}+k_{L} \times M_{L}}
$$

Permeability for diffusive exchange between leaves and air. Chemicals in air come onto/into/out of leaves by various ways: gaseous through the cuticles; gaseous through stomata; by dry particulate deposition; by wet particulate deposition. The deposition velocities for all these uptake pathways depend crucially on chemical and environmental properties. A rough estimate is that the deposition velocity from leaves to air, the conductance $\mathrm{g}$, is about $10^{-3} \mathrm{~m} \mathrm{~s}^{-1}$ for gaseous and particulate deposition [9]. Hereby, conductance $\mathrm{g}\left(\mathrm{m} \mathrm{s}^{-1}\right)$ is related to concentrations in the gas phase. It is identical to $\mathrm{P} / \mathrm{K}_{\mathrm{AW}}$, where $\mathrm{P}$ is the permeability related to concentrations in water. The contributions of the various resistances to the overall permeability are described in appendix 2.

2.1.5 Fruits. The mass balance for chemicals in fruits is handled similar to the mass balance in leaves. Uptake is from stem (via phloem and xylem) or from air, and loss is by metabolism and to air. The concentration in fruits is calculated by

$$
\frac{d C_{F}}{d t}=+\frac{Q_{F}}{M_{F}} \times C_{X y 3}+\frac{A_{F} \times P_{F}}{K_{A W} \times M_{F}} \times C_{A i r}-\frac{1000 \times A_{F} \times P_{F}}{K_{F W} \times M_{F}} \times C_{F}-k_{F} \times C_{F}
$$

In steady-state: 


$$
C_{F}=\frac{Q_{F} \times C_{X y 3}+A_{F} \times P_{F} \times \frac{C_{A}}{K_{A W}}}{\frac{1000 \times A_{F} \times P_{F}}{K_{F W}}+k \times M_{L}}
$$

where $F$ is the index for fruits. $Q_{F}$ is the sum of phloem and xylem flow $\left(\mathrm{L} \mathrm{d}^{-1}\right), \mathrm{K}_{\mathrm{FW}}(\mathrm{L}$ $\mathrm{kg}^{-1}$ ) is the partition coefficient between fruits and water, calculated as for leaves but with other water and lipid content. $\mathrm{P}_{\mathrm{F}}$ is the permeability for exchange between fruits and air $\left(\mathrm{m} \mathrm{d}^{-1}\right)$.

Phloem and xylem flow. In young (green) apples, the flow of xylem and phloem to fruits occurs at approximately same rates [20]. Later, phloem flow dominates. While the phloem is loaded in leaves, the xylem has its origin in the roots. In the model, currently no difference is made between chemical concentration in phloem and in xylem. This is because both streams are neighbored within branches and stem, and a diffusive exchange may occur. Xylem flow is orders of amounts larger, so it is likely that the mixture will have a concentration close to the original xylem sap. Phloem transport downwards (in opposite direction to the xylem) is relevant for weak acids, due to the ion trap effect [21]. All other compounds do not accumulate in phloem, compared to the xylem. Transport in opposite direction of the xylem may also occur for neutral compounds, which are very polar and thus leave the phloem sieve tubes very slowly [22]. For the less polar neutral compounds, xylem and phloem concentrations will equilibrate within short distance, as it is handled in the model. The xylem flow to leaves $\mathrm{Q}_{\mathrm{L}}\left(\mathrm{L} \mathrm{d}^{-1}\right)$ and fruits $\mathrm{Q}_{\mathrm{FX}}\left(\mathrm{L} \mathrm{d}^{-1}\right)$ is calculated from the total xylem flow out of the stem $\mathrm{Q}_{\mathrm{St}}$ by averaging with the respective surface areas:

$$
Q_{F X}=\frac{A_{F}}{A_{F}+A_{L}} \times Q_{S t}
$$


and $\mathrm{Q}_{\mathrm{L}}+\mathrm{Q}_{\mathrm{FX}}=\mathrm{Q}_{\mathrm{St}}$

The phloem flux into fruits is calculated as in the first Fruit Tree Model [14]: Fruits are "fed" via phloem. Phloem sap has high dry matter content, about 10\%. This dry matter remains in the fruit. Therefore, it may be assumed that the total phloem flow into fruits, Sum $\mathrm{Q}_{\mathrm{FP}}(\mathrm{L})$ is about 10 times the dry matter content:

Sum $\mathrm{Q}_{\mathrm{FP}}=\left(1-\mathrm{W}_{\mathrm{F}}\right) \times \mathrm{M}_{\mathrm{F}} \times 10$

, where $\left(1-\mathrm{W}_{\mathrm{F}}\right) \times \mathrm{M}_{\mathrm{F}}$ is the dry mass of the fruit. The daily phloem sap flow into fruits, $\mathrm{Q}_{\mathrm{FP}}\left(\mathrm{L} \mathrm{d}^{-1}\right)$, is calculated by dividing Sum $\mathrm{Q}_{\mathrm{FP}}$ with 60 days, $\mathrm{Q}_{\mathrm{FP}}=\operatorname{Sum} \mathrm{Q}_{\mathrm{FP}} / 60 \mathrm{~d}$. The total water flux into fruits $\mathrm{Q}_{\mathrm{F}}$ is the sum of xylem and phloem flux:

$\mathrm{Q}_{\mathrm{F}}=\mathrm{Q}_{\mathrm{FX}}+\mathrm{Q}_{\mathrm{FP}}$

Permeability. Loss via stomata and cuticles is considered, as before, by $\mathrm{P}_{\mathrm{S}}$ and $\mathrm{P}_{\mathrm{C}} \cdot \mathrm{P}_{\mathrm{S}}$ is calculated from $\mathrm{Q}_{\mathrm{FX}}$ (xylem flow) and $\mathrm{A}_{\mathrm{F}}$. For $\mathrm{P}_{\mathrm{C}}$ of the fruit, the same value as for leaves is used. The resistance of the fruit tissue $\mathrm{P}_{\text {tissue }}$ is added, calculated in the same way as for roots, but with water and gas fraction of the fruit and with a default diffusion length of $1 \mathrm{~cm}$. The total permeability for the exchange between fruits and air is then

$$
P_{F}=\frac{1}{\frac{1}{P_{C}+P_{S}}+\frac{1}{P_{\text {tissue }}}}
$$

\subsection{Input Data}


An example data set for $1 \mathrm{~m}^{2}$ apple orchard is given in Tables 1 to 3 . The data is not for a special situation or from one single experiment, but taken from textbooks, nutrition tables, former model versions, or based on experience. Furthermore, the data does not consider changes with time, because it is input to a steady-state calculation.

[Please place here Table 1]

[Please place here Table 2]

[Please place here Table 3]

\section{Discussion}

\subsection{Sensitivity study for chemical input parameters}

The model requires four chemical input data, namely $\mathrm{K}_{\mathrm{OW}}, \mathrm{K}_{\mathrm{AW}}$, molar mass $\mathrm{M}$ and metabolism rate $(\mathrm{s}) \mathrm{k}_{\mathrm{m}}$. Metabolism rates for chemicals in apple trees are largely unknown and set to $\mathrm{k}_{\mathrm{m}}=0$ by default. Molar mass $\mathrm{M}$ has only marginal influence via diffusion constants $\mathrm{D}_{\mathrm{W}}$ and $\mathrm{D}_{\mathrm{G}}$. The octanol-water partition coefficient $\mathrm{K}_{\mathrm{OW}}$ is a common measure for lipophilicity. Values may range from $<2$ for hydrophilic to $>6$ for very lipophilic compounds. $\mathrm{K}_{\mathrm{Aw}}$, the dimensionless Henry's Law constant, may range from $>10$ for very volatile to $<10^{-9}$ for non-volatile compounds. The ratio $\mathrm{K}_{\mathrm{OW}} / \mathrm{K}_{\mathrm{AW}}$ is also known as octanol-air partition coefficient $\mathrm{K}_{\mathrm{OA}}$. In Figure 3 abc, the chemical space made up by $\mathrm{K}_{\mathrm{OW}}$ and $\mathrm{K}_{\mathrm{AW}}$ is plotted (log-scale, z-axis crosses at 0.01 ) versus simulated concentrations in stem $(z=5 \mathrm{~m})$, leaves and fruits for the scenario uptake from soil layer 1 by fine roots $\left(\mathrm{C}_{\text {Soill }}=1 \mathrm{mg} \mathrm{kg}^{-1}\right)$. Accumulation in stem is relatively homogenous and requires a low $\mathrm{K}_{\mathrm{AW}}(\leq 0.1)$ and medium to $\operatorname{low} \log \mathrm{K}_{\mathrm{OW}}(\leq 4)$. 
Accumulation in leaves occurs preferably at smaller $\mathrm{K}_{\mathrm{AW}}\left(\leq 10^{-5}\right)$ and for the more polar compounds $\left(\log \mathrm{K}_{\mathrm{OW}} \leq 2\right)$. Absolute values can be rather high $\left(\mathrm{C}_{\mathrm{L}} / \mathrm{C}_{\text {Soil }}>100\right)$. Accumulation in apples from soil occurs for chemicals with the same properties, but is generally lower. Figure 4 abc shows the chemical space versus simulated concentrations

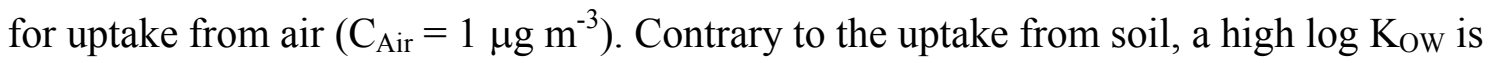
required for high accumulation, but still a low $\mathrm{K}_{\mathrm{Aw}}$. Or, with $\mathrm{K}_{\mathrm{OW}} / \mathrm{K}_{\mathrm{AW}}=\mathrm{K}_{\mathrm{OA}}$, the uptake from air increases with the octanol-air partition coefficient. The relation is not directly proportional: for very high $\log \mathrm{K}_{\mathrm{OA}}$-values, the uptake into leaves and fruits is kinetically limited and reduced by growth dilution. The highest accumulation is predicted for stem. However, in reality, an accumulation of very lipophilic compounds is restricted to the outer bark [25], where the lipophilics are retained [12]. This effect cannot be simulated in a 1-D model. The accumulation in apples is comparatively low, both due to the low lipid content and the slow transfer due to the low surface-to-volume ratio.

[Please place here Figures $3 \mathrm{a} \mathrm{b} \mathrm{c}$ ]

[Please place here Figures $4 \mathrm{a} \mathrm{b} \mathrm{c}$ ]

Time scale. The model is based on a steady-state solution, so the dynamics of the concentration change cannot be considered. It is also the question whether steady-state is reached at all within one growth season or the life-span of a tree. Of all compartments, stem has the biggest volume and the smallest surface-to-volume ratio. It has thus the longest exchange and travel times for all compounds. Characteristic times can be defined. One is the travel time $t_{\text {stem }}(d)$, which is the time needed for a compound to flow with the transpiration stream from the bottom of the stem to the top: 
$t_{\text {stem }}=\frac{z}{u_{c}}$

where $\mathrm{z}$ is the stem height and $\mathrm{u}_{\mathrm{c}}$ is the flow velocity of the chemical.

Another characteristic time is the half-time of loss from the stem, $t_{12}(d)$, which is

$t_{12}=\frac{\ln 2}{k}$

where $\mathrm{k}$ is the sum of the stem's growth rate and the loss rate (via volatilization) from stem.

Figure 5 shows the travel time in the stem. It grows exponentially with the log $\mathrm{K}_{\mathrm{OW}}$, from 0.125 days for a very polar chemical (that does not adsorb to the stem) to $>1000$ days for a chemical with $\log \mathrm{K}_{\mathrm{OW}}=6$. Figure 6 shows the half-time for loss from stem. The minimum, which is less than 0.2 days, is for volatile compounds $\left(\mathrm{K}_{\mathrm{AW}}=10\right)$ with intermediate lipophilicity $\left(\log \mathrm{K}_{\mathrm{OW}}=2\right)$. The half-time for loss increases to values $>10$ 000 days for very non-volatile compounds $\left(\mathrm{K}_{\mathrm{AW}}=10^{-9}\right)$ and very lipophilic compounds $\left(\log \mathrm{K}_{\mathrm{OW}}=6\right)$. Note that the loss-rate to air is also related to the uptake from air. As a general rule, a system is close to steady-state after 3 to 4 half-times. This means, that for the very non-volatile and lipophilic compounds, the concentrations in the tree do probably never reach steady-state.

[Please place here Figure 5]

[Please place here Figure 6] 


\subsection{Limitations}

Limitations of the model stem from underlying assumptions, process consideration and formulation, data selection and from the type of solution. First of all, the model is strictly limited to neutral compounds; it is not applicable to ions or dissociating compounds, for which the Nernst-Planck equation describes diffusion [26]. If metabolism of the compound in planta occurs, this may be of a Michaelis-Menten type, leading to non-linear relations between outside and inside concentrations. This means that for low exposure, the concentrations inside plants are near zero. At higher exposure,

the enzyme system of the plant is overloaded, and accumulation occurs [27]. The transformation of chemicals by plant enzymes is hard to forecast, but enzymatic reactions occur in solution, and thus, transformation is generally more likely for soluble compounds (small $\mathrm{K}_{\mathrm{OW}}$ ). A process not formulated in the model is particle deposition. It is well known that for strongly sorbed compounds, particle resuspension from soil may be the dominating transport process from soil to leaves [28, 29]. However, this process is only relevant for plant parts near the soil surface. Particle deposition from atmosphere is the dominating transport process to leaves for chemicals with high $\log \mathrm{K}_{\mathrm{OA}}$ [30]. Whether this is also the case for fruits is unknown, but likely. If wet and dry particulate deposition are added (method described in [11]), uptake from air is higher for chemicals with very low vapour pressure (high $\mathrm{K}_{\mathrm{OA}}$ ).

Branches have a much smaller diameter than stems, and their bark is very thin. This means the diffusion pathway for exchange with air is rather small, too, and the diffusive exchange is thus high, even though the time the chemical resides in the branches is comparatively low. The loss (or gain) might be far higher than from stems. If experiments validate these considerations, it would be necessary to add a branch compartment to the model, in order to yield realistic results for volatile compounds. 
The differential equations were, for the sake of a compact model with low data needs, solved for the steady-state. Growth is considered as exponential. Deviations to reality may occur for these reasons.

The model is a deterministic model, strictly simplified in an attempt to describe a complex (living) environmental system. The purpose is not to predict exactly the concentration of a given compound for a given situation (soil, crop, climate, application) - this might be better done by more simple empirical models. The purpose is to gain an insight into the processes, their relevance in connection with other parameters and for the wide variety of chemicals. This is helpful in understanding the complex processes occurring simultaneously in reality and thus gives a guide at hand for designing experimental studies and interpreting their results. It may also help in finding more simple (reduced) empirical relations, which may hold only for a limited scope, but may be precise within a certain range.

\subsection{Validity of the model}

A greenhouse-study with radio-labeled trichloroethene (TCE) and apple and peach trees was undertaken by Chard et al. [31]. Even though TCE could not directly be detected in apples, it was concluded from ${ }^{14} \mathrm{C}$-measurements that the concentration ratio to soil (BCF) was between 0.01 and 0.07 fresh fruit / wet soil. The result with the Fruit Tree Model for TCE $\left(\log \mathrm{K}_{\mathrm{OW}} \sim 3, \mathrm{~K}_{\mathrm{AW}} \sim 0.2\right)$ is 0.04 . Another experiment was done with the chemical sulfolane $\left(\log \mathrm{K}_{\mathrm{OW}}=-0.8, \mathrm{~K}_{\mathrm{AW}} \sim 10^{-9}\right)$. The concentration ratio fruit to soil was 2.8 , while the model would give a value of 8.2 (scenario: input via soil 1 and soil

2). For leaves, a BCF of 652 was found, which seems rather high. However, the model, 
too, gave a BCF of 286. This means that the model is well able to identify compounds with very high uptake from soil.

No other full-scale study for uptake of organic environmental chemicals from soil into apples is available, but several aspects of the model can be compared to experimental results. The diffusion coefficient of TCE in poplar stem was determined [17] and ranged from $5 \times 10^{-7}$ to $2 \times 10^{-6} \mathrm{~cm}^{2} \mathrm{~s}^{-1}$, while the model gives $1.2 \times 10^{-6} \mathrm{~cm}^{2} \mathrm{~s}^{-1}$. The movement of TCE in tree trunks was determined [32]. The loss with height was between $70 \%$ and $53 \%$ for 17 to $18.6 \mathrm{~m}$ height. The model gives a loss of $64 \%$ with 17 m height. PCDD/F uptake from air was the major pathway for contamination of pear and apple fruits [33]. This is in accordance with the model predictions for lipophilic semivolatile compounds (Figs. 3 and 4). The transport velocity of lipophilic compounds in soybean stems, compared to water, is reduced, as predicted by the model [34].

TSCF. In 1974, Shone et al. [35] introduced the transpiration stream concentration factor TSCF, which is the ratio of the concentration in xylem to that in external solution and is a measure for translocation upwards. Briggs et al. fitted the characteristic bellshaped (Gaussian) curve to the $\log \mathrm{K}_{\mathrm{OW}}[16]$ :

$\mathrm{TSCF}=0.784 \times \exp \left\{\frac{-\left(\log \mathrm{K}_{\mathrm{OW}}-1.78\right)^{2}}{2.44}\right\}$

This curve was confirmed [36] and used frequently in plant uptake models $[1,2,8,9,10,11,12,14,15,19$ and others]. The TSCF does not appear in the equations of the new fruit tree model. The model can nonetheless reproduce this optimum curve. If uptake is only from thick roots $\left(\mathrm{C}_{\text {Soil1 }}=0\right)$, the calculated concentration ratio of xylem $\left(\mathrm{C}_{\mathrm{Xy} 2}\right.$, out of thick roots) to soil water $\left(\mathrm{C}_{\mathrm{W} 2}\right)$ is rather similar to the TSCF-regression of 
Briggs et al. (Figure 7). This is due to slow uptake of very polar compounds (resistance of the root biomembrane), and to growth dilution of the very non-polar compounds. However, if uptake from fine roots is added $\left(\mathrm{C}_{\text {Soil1 }} \neq 0\right)$, the TSCF of polar compounds is high. Interestingly, plants produce root hairs (fine roots) only in soil or in water vapour, but never in hydroponic solution (own observation). The experiments of Briggs et al. [16] and of Burken and Schnoor [36] were done in hydroponic solution, and the optimum curve was observed. For experiments done in soil [31] or fine sand [27], no reduced uptake of polar compounds could be observed. A sensitivity study shows that many parameters influence the TSCF (and thus the translocation upwards). For polar compounds, transpiration stream and a couple of root parameters, such as water- and gas pores, radius (and subsequently surface area), mass and permeability (mainly of the biomembrane) are sensitive for the TSCF. For lipophilic compounds, transpiration, lipid content, root mass and growth rate influence the TSCF most. It can thus be expected that the TSCF is not a constant, but varies largely with the conditions.

To summarize, so far there have not been conflicting experimental results that would falsify the model output.

[Please place here Figure 7]

\subsection{Comparison of new and former fruit tree model}

The first fruit tree model was published in 2003 [14]. It was purely based on advection and did not consider diffusive exchange processes. This made the mass balance equations easy, as geometry and permeabilities could be ignored. On the other hand, the model was limited to non-volatile compounds and could not consider uptake from air. 
Another difference is that the concept of TSCF was omitted in the new model version. Indeed, this yields more accurate results [31].

\section{Conclusions and outlook}

A new fruit tree model was developed, considering eight compartments and using equilibrium, advective transport, diffusive exchanges and growth dilution as main processes. The model predicts that polar, non-volatile compounds will effectively be transported from soil to fruits, while lipophilic, non-volatile compounds will accumulate from air into fruits. Measured results show no disagreement with the model predictions. The model might assist in designing and interpreting experimental studies, and be useful for human exposure assessment.

The new model concept might furthermore be the base of a series of models for other food crops, such as wheat, maize, rice and other types of fruits and fruit vegetables. Only minor adaptions will be necessary, and other input data.

Please contact the author for a free spread-sheet version of the Fruit Tree Model.

\section{Acknowledgements}

This work was partly funded by the European Commission, project BIOTOOL, contract no. 003998 (GOCE). Many thanks go to Joel Burken, University of Missouri-Rolla, for very inspiring talks and discussions, and to James Deviller, CTIS France, for his invitation to contribute to QSAR 2006. 


\section{Appendix 1: The permeability $P$ for roots}

The basis to describe the exchange across boundaries between different compartments is Fick's 1st Law of diffusion:

$\frac{d m_{12}}{d t}=-A \times \frac{D}{\Delta x} \times\left(C_{1}-C_{2}\right)$

where $\mathrm{m}$ is the mass of chemical $(\mathrm{mg}), \mathrm{t}$ is the time $(\mathrm{d}), \mathrm{dm}_{12} / \mathrm{dt}$ is the flux of chemical from compartment 1 to compartment $2\left(\mathrm{mg} \mathrm{d}^{-1}\right), \mathrm{A}$ is the exchange area $\left(\mathrm{m}^{2}\right), \mathrm{D}$ is the diffusion coefficient $\left(\mathrm{m}^{2} \mathrm{~d}^{-1}\right), \Delta \mathrm{x}$ is the diffusion length $(\mathrm{m}), \mathrm{C}$ is the concentration $\left(\mathrm{mg} \mathrm{m}^{-3}\right)$ and 1 and 2 are indicating phase 1 and 2 . It is common to name the ratio $\mathrm{D} / \Delta \mathrm{x}$ "permeability" $\mathrm{P}\left(\mathrm{m} \mathrm{d}^{-1}\right)$, synonyms are exchange velocity, transfer velocity or conductivity. If the concentration ratio between phase 1 and 2 in equilibrium is not 1 , the partition coefficient $\mathrm{K}$ needs to adjust this.

$\frac{d m_{12}}{d t}=A \times P \times\left(C_{1}-C_{2} / K_{21}\right)$

Now, $\mathrm{P}$ is phase-specific. The following definitions are made:

1st: All diffusive fluxes are related to the water phase.

2nd: The term "permeability" $\mathrm{P}$ (unit $\mathrm{m} \mathrm{d}^{-1}$ ) is used for all diffusive exchanges.

3rd: For solids (plants and soil), concentrations are expressed in the unit $\mathrm{mg} \mathrm{kg}^{-1}$. For liquids (soil solution, xylem sap), the unit $\mathrm{mg} \mathrm{L}^{-1}$ is used. For gas (air), the unit $\mathrm{mg} \mathrm{m}^{-3}$ is used. This requires scaling factors. For roots, Fick's 1st Law of Diffusion is

$\frac{d m_{R W}}{d t}=A_{R} \times P_{R} \times 1000 \times\left(C_{W}-C_{R} / K_{R W}\right)$

where A is the surface area of root $R\left(\mathrm{~m}^{2}\right), \mathrm{P}$ is the permeability $\left(\mathrm{m} \mathrm{d}^{-1}\right), \mathrm{C}_{\mathrm{W}}$ is the concentration of the chemical in soil solution (water, $\left.\mathrm{mg} \mathrm{L}^{-1}\right), \mathrm{C}_{\mathrm{R}}$ is the concentration in root $\left(\mathrm{mg} \mathrm{kg}^{-1}\right)$, and $\mathrm{K}_{\mathrm{RW}}$ is the partition coefficient between root and water $\left(\mathrm{L} \mathrm{kg}^{-1}\right)$. The factor 1000 is the scaling factor from $\mathrm{m}^{3} \mathrm{~d}^{-1}$ to $\mathrm{L}$ $\mathrm{d}^{-1}$.

Permeability of the root. It is assumed that the major resistance to diffusive exchange is within the root tissue. $\mathrm{P}$ is estimated in the following way: Only the dissolved fraction of chemical, $\mathrm{f}_{\mathrm{W}}$, and the gaseous fraction of chemical, $\mathrm{f}_{\mathrm{G}}$, are mobile and can diffuse, while the adsorbed fraction of the chemical is considered immobile. The fraction of chemical $f_{W}(-)$ dissolved in the water $W_{R}$ of the root is $f_{W}=\frac{C_{\text {Rootwater }}}{C_{\text {totalRoot }}}=\frac{W_{R}}{K_{R W}}$ 
The fraction of chemical $\mathrm{f}_{\mathrm{G}}(-)$ present in gas pores $G_{R}\left(\mathrm{~L} \mathrm{~kg}^{-1}\right)$ of the root is

$f_{G}=\frac{G_{R} \times K_{A W}}{K_{R W}}$

The diffusion coefficients of chemicals are related to the square root of the molar mass $\mathrm{M}\left(\mathrm{g} \mathrm{mol}^{-1}\right)$. The diffusion coefficient of the chemical in pure water $\mathrm{D}_{\mathrm{W}}$ related to the diffusion coefficient of oxygen in water $\mathrm{D}_{\mathrm{O} 2}$ is [11]

$D_{W}=D_{O 2} \times \frac{\sqrt{32}}{\sqrt{M}}$

where $\mathrm{D}_{\mathrm{O} 2}$ is the diffusion coefficient of oxygen $\mathrm{O}_{2}\left(\mathrm{M}=32 \mathrm{~g} \mathrm{~mol}^{-1}\right)$ in water $=1.728 \times 10^{-4} \mathrm{~m}^{2} \mathrm{~d}^{-1}$. For the estimation of the diffusion coefficient in gas $\mathrm{D}_{\mathrm{G}}$, the diffusion coefficient of water vapour $\mathrm{D}_{\mathrm{H} 2 \mathrm{O}}$ in air is used:

$D_{G}=D_{H 2 O} \times \frac{\sqrt{18}}{\sqrt{M}}$

, with $\mathrm{D}_{\mathrm{H} 2 \mathrm{O}}=2.22 \mathrm{~m}^{2} \mathrm{~d}^{-1}$. In porous solids (such as plant tissue), the diffusion is hampered by a "labyrinth factor", named tortuosity T. This tortuosity is estimated by the method of Millington and Quirk [37], for diffusion in root water and gas pores:

$T_{W}=\frac{W_{R}^{10 / 3}}{\left(W_{R}+G_{R}\right)^{2}}$

$T_{G}=\frac{G_{R}^{10 / 3}}{\left(W_{R}+G_{R}\right)^{2}}$

The effective diffusion coefficient in the water pores of the roots is then

$D_{W, e f f}=D_{W} \times f_{W} \times T_{W}$

and in the gas pores it is

$D_{G, e f f}=D_{G} \times f_{G} \times T_{G}$

The sum of both gives the diffusion coefficient of the chemical in root tissue $D_{R}\left(\mathrm{~m}^{2} \mathrm{~d}^{-1}\right)$

$D_{R}=D_{W, e f f}+D_{G, e f f}$

and by division by the diffusion length $(\mathrm{m})$, the permeability of the root tissue, $P_{\text {tissue }}\left(\mathrm{m} \mathrm{d}^{-1}\right)$, is found

$P_{\text {tissue }}=\frac{D_{R}}{\Delta x}$ 
The diffusion length, $\Delta \mathrm{x}(\mathrm{m})$, is set to $1 / 2$ radius of the root. For polar compounds, the root biomembrane provides an additional resistance. The permeability of the root biomembrane, $\mathrm{P}_{\mathrm{M}}$, is estimated with [26] $P_{M}=86400 \times 10^{\log K_{O W}-6.7}$

The total permeability of the roots, $\mathrm{P}_{\mathrm{R}}\left(\mathrm{m} \mathrm{d}^{-1}\right)$, is then $P_{R}=\frac{1}{\frac{1}{P_{\text {tissue }}}+\frac{1}{P_{M}}}$

\section{Appendix 2: Permeability of leaves}

Stomata. If the water loss $\mathrm{Q}\left(\mathrm{L} \mathrm{d}^{-1}\right)$ by transpiration and the leaf surface area $\mathrm{A}\left(\mathrm{m}^{2}\right)$ of the plant are known, there is an easy way to estimate the resistance of the stomatal pathway. It requires furthermore temperature and relative humidity. The loss of water from leaves is assumed to follow Fick's 1st Law:

$\frac{d m_{\mathrm{H} 2 \mathrm{O}}}{d t}=A \times g \times\left(C_{H_{2} \mathrm{O}, \text { Leaf }}-C_{\mathrm{H}_{2} \mathrm{O}, \mathrm{Air}}\right)$

The loss of water, $\mathrm{dm}_{\mathrm{H} 2 \mathrm{O}} / \mathrm{dt}\left(\mathrm{kg}\right.$ water $\left.\mathrm{d}^{-1}\right)$, is identical to the transpiration $\mathrm{Q}\left(\mathrm{L} \mathrm{d}^{-1}\right)$, if the density of water is assumed to be $1 \mathrm{~kg} \mathrm{~L}^{-1}$. The equation can be rearranged to

$$
g_{H 2 O}=\frac{Q}{A \times\left(C_{H 2 O, \text { Leaf }}-C_{H 2 O, \text { Air }}\right)}
$$

where $\mathrm{g}\left(\mathrm{m} \mathrm{d}^{-1}\right)$ is the conductance of the stomatal pathway for water. The (gas-phase) concentration of water inside the leaves, $\mathrm{C}_{\mathrm{H} 2 \mathrm{O} \text {,Leaf }}\left(\mathrm{kg} \mathrm{m}^{-3}\right)$ can be calculated from the temperature, assuming that the interior of the leaf is water-saturated. The saturation vapour pressure of water $\mathrm{p}_{\mathrm{H} 2 \mathrm{O} \text {,sat }}(\mathrm{Pa})$ at given temperature Temp $\left({ }^{\circ} \mathrm{C}\right)$ may be calculated by the empirical Magnus-equation:

$p_{H 2 O, \text { sat }}=610.7 \times 10^{\frac{7.5 \times T e m p}{237+T e m p}}$ (note: it is really 237 and not 273 ).

The Ideal Law of Gases states that

$\frac{p}{R \times T}=\frac{n}{V}$

where $\mathrm{p}$ is the vapour pressure (of water), $\mathrm{R}$ is the universal gas constant $\left(8.314 \mathrm{~J} \mathrm{~mol}^{-1} \mathrm{~K}^{-1}\right), \mathrm{T}$ is the absolute temperature $(\mathrm{K})=\operatorname{Temp}\left({ }^{\circ} \mathrm{C}\right)+273.15, \mathrm{n}$ is the amount of water molecules $(\mathrm{mol})$ and $\mathrm{V}$ is the 
volume $\left(\mathrm{m}^{3}\right)$. Remains to recalculate from mol $\mathrm{H}_{2} \mathrm{O} \mathrm{m} \mathrm{m}^{-3}$ to $\mathrm{kg} \mathrm{H}_{2} \mathrm{O} \mathrm{m} \mathrm{m}^{-3},\left(1 \mathrm{~mol} \mathrm{H}_{2} \mathrm{O}=0.018 \mathrm{~kg}\right)$, which gives the saturation water concentration at leaf temperature:

$C_{H 2 O, s a t}=\frac{p_{H 2 O}}{461.9 \times T}$

The concentration of water vapour in air is simply the saturation water concentration times the relative humidity rh (-). To be exact, the leaf temperature and the air temperature should be used, which may differ to some degrees. However, for humidities $<<1$, this would not play a major role. We receive the equation

$g_{\mathrm{H} 2 \mathrm{O}}=\frac{Q}{A \times\left(C_{H_{2 O}, \mathrm{sat}}-r h \times C_{H_{2 O}, \mathrm{sat}}\right)}$

To come from the conductance of water to that of the chemical, we use the fact that

$g=\frac{D_{G}}{\Delta x}$

The diffusion pathway does not change with the chemical, while the diffusion coefficient does, and so

$g_{S}=g_{H 2 O} \times \frac{\sqrt{18}}{\sqrt{M}}$

where $\mathrm{g}_{\mathrm{S}}\left(\mathrm{m} \mathrm{d}^{-1}\right)$ is the conductance for the stomatal exchange between leaves and air for a chemical with molar mass $\mathrm{M}\left(\mathrm{g} \mathrm{mol}^{-1}\right)$. The permeability $\mathrm{P}_{\mathrm{S}}\left(\mathrm{m} \mathrm{d}^{-1}\right)$ of the stomatal pathway, related to water, is then conductance times partition coefficient air-water $\mathrm{K}_{\mathrm{AW}}$ :

$P_{S}=g_{S} \times K_{A W}$

Cuticles. The cuticle is a waxy layer all around the leaf. A regression equation derived for the permeability $P_{C}$ of citrus cuticles is [38]

$P_{C}=10^{0.704 \times \log K o w-11.2}\left(\mathrm{~m} \mathrm{~s}^{-1}\right)$

Air boundary layer. After the chemical has crossed the cuticle, the next resistance is provided by the air boundary layer around the leaf. It plays a role for compounds with low $\mathrm{K}_{\mathrm{AW}}$. A resistance of $200 \mathrm{~m} \mathrm{~s}^{-1}$ was estimated as typical for a chemical with molar weight $\mathrm{M}=300 \mathrm{~g} \mathrm{~mol}^{-1}$ [39]. The conductance of the air boundary layer, $\mathrm{g}_{\text {Air }}$, for a chemical with molar mass $\mathrm{M}$ is thus

$g_{\text {Air }}=\frac{1}{200} \times \frac{\sqrt{300}}{\sqrt{M}}\left(\mathrm{~m} \mathrm{~s}^{-1}\right)$ 
The total permeability of the cuticle pathway $\left(\mathrm{m} \mathrm{d}^{-1}\right)$ is

$P_{C, \text { total }}=\frac{1}{\frac{1}{P_{C}}+\frac{1}{g_{A i r} \times K_{A W}}} \times 86400$

The exchanges of the chemical through cuticle and stomata occur in parallel, and thus the permeabilities are added to derive the total permeability for the exchange between leaf and air, $\mathrm{P}_{\mathrm{L}}\left(\mathrm{m} \mathrm{d}^{-1}\right)$ :

$P_{L}=P_{S}+P_{\text {C.total }}$

Chemicals with very low vapour pressure (high $\mathrm{K}_{\mathrm{OA}}$ ) are predominantly bound to particles. It is recommended to consider dry and wet particle deposition. A methodology is given in the CemoS handbook [11]. For chemicals with very low $\mathrm{K}_{\mathrm{AW}}\left(<10^{-6}\right)$, wet gaseous deposition becomes relevant. 


\section{References}

[1] European Commission. Technical Guidance Document in Support of Commission Directive 93/67/EEC on Risk Assessment for New Notified Substances and Commission Regulation (EC) No 1488/94 on Risk Assessment for Existing Substances. European Commission, Office for Official Publications of the European Communities, Luxemburg, Luxemburg (1996).

[2] European Commission: EUSES, the European Union System for the Evaluation of Substances. National Institute of Public Health and the Environment (RIVM), The Netherlands (1996).

[3] S. Himmerich, H. Seiler, K. Gedrich, J. Linseisen. Bayrische Verzehrsstudie (BVS II) Abschlussbericht. Report im Auftrag des Bayerischen Staatsministeriums für Umwelt, Gesundheit und Verbraucherschutz (2003).

[4] G. Rippen. Handbuch Umweltchemikalien. ecomed, Landsberg a.L., D (2006).

[5] European Commission: Council Directive 98/83/EC of 3 November 1998, on the quality of water intended for human consumption. Official Journal of the European Communities, L 330/32 (1998).

[6] European Food Safety Authority. Pesticides are EU citizens' top food-related health concern. Available online at http://www.euractiv.com (accessed 17 March 2006). 
[7] Bundesamt für Verbraucherschutz und Lebensmittelsicherheit. National report on pesticide residues in foodstuff. Available online at www.bvl.bund.de/berichtpsm (accessed 17 March 2006).

[8] S. Trapp, J.C. Mc Farlane, M. Matthies. Environ. Toxicol. Chem. 13, 413 (1994).

[9] S. Trapp, M. Matthies. Environ. Sci. Technol. 29, 2333-2338; erratum 30, 360 (1995).

[10] S. Trapp, J.C. Mc Farlane (Eds.). Plant Contamination. Modeling and Simulation of Organic Chemical Processes. Lewis Pub., Boca Raton, FL (1995).

[11] S. Trapp, M. Matthies. Chemodynamics and Environmental Modeling. Springer, Heidelberg, D (1998).

[12] S. Trapp, K.S.B. Miglioranza, H. Mosbæk. Environ. Sci. Technol. 35, 1561 (2001).

[13] S. Trapp. Environ. Toxicol. Chem. 21, 203 (2002).

[14] S. Trapp, D. Rasmussen, L. Samsøe-Petersen. SAR - QSAR Environ. Res. 14, 17 (2003).

[15] S. Trapp, M. Matthies, I. Scheunert, E.M. Topp. Environ. Sci. Technol. 24, 1246 (1990).

[16] G.G. Briggs, R.H. Bromilow, A.A. Evans Pestic. Sci. 13, 495 (1982). 
[17] X. Ma, J. Burken. Environ. Sci. Technol. 38, 4580 (2004).

[18] B. Huber. Die Saftströme der Pflanzen, p. 42, Springer, Berlin, D (1956).

[19] S. Trapp. In Plant Contamination. Modeling and Simulation of Organic Chemical Processes, S. Trapp, J.C. Mc Farlane (Eds.), pp. 107-151, Lewis Pub., Boca Raton, FL (1995).

[20] A. Lang. J. Exp. Bot. 41, 645 (1990).

[21] D.A. Kleier. Plant Physiol. 86, 803 (1988).

[22] R.H. Bromilow, K. Chamberlain. In Plant Contamination. Modeling and Simulation of Organic Chemical Processes, S. Trapp, J.C. Mc Farlane (Eds.), pp. 37-68, Lewis Pub., Boca Raton, FL (1995).

[23] I. Elmadfa, W. Aign, E. Muskat, D. Fritsche, H.-D. Cremer. Die grosse GU Nährwert Tabelle. Gräfe und Unzer, Giessen, D (1991).

[24] L.C. Davis, L.E. Erickson, C.T. Jones. Rev. Biotech. 7, 43 (1987).

[25] M.L. Meredith, R.A. Hites. Environ. Sci. Technol. 21, 709 (1987).

[26] S. Trapp. Environ. Sci. \& Pollut. Res. 11, 33 (2004). 
[27] M. Larsen, A. Ucisik, S. Trapp. Environ. Sci. Technol. 39, 2135 (2005).

[28] J.G. Li, M.H. Gerzabek, K. Mück. Die Bodenkultur 45, 15 (1994).

[29] S. Trapp, S. Schwartz. Chemosphere 41, 965 (2000).

[30] M. Horstmann, M. McLachlan. Atmos. Environ. 32, 1799 (1998).

[31] B.K. Chard, W.J. Doucette, J.K. Chard, B. Bugbee, K. Gorder. Trichloroethylene uptake by apple and peach trees: greenhouse study. Environ. Sci. Technol. 40, 4788.

[32] D.A. Vroblesky, C.T. Nietch, J.T. Morris. Environ. Sci. Technol. 33, 510 (1999).

[33] J.F. Müller, A. Hülster, O. Päpke, M. Ball, H. Marschner. Chemosphere 27, 195 (1993).

[34] J.K. McCrady, C. McFarlane, F.T. Lindstrom. J. Exp. Bot. 38, 1875 (1987).

[35] M.G.T. Shone, O.B. Bartlett, A.V. Wood J. Exp. Bot. 25, 401 (1974).

[36] J.G. Burken, J.L. Schnoor. Environ. Sci. Technol. 32, 3379 (1998).

[37] W.A. Jury, W.F. Spencer, W.J. Farmer. J. Environ. Qual. 12, 558 (1983); erratum 16, 448 .

[38] F. Kerler, J. Schönherr. Arch. Environ. Contam. Toxicol. 17, 7 (1988). 
[39] N. Thompson. Pestic. Sci. 14, 33 (1983). 
Table 1. Soil data (assumed identical for soil layer 1 and 2).

\begin{tabular}{lcccc}
\hline Parameter & Symbol & Value & Unit & Reference \\
\hline Soil wet density & $\rho_{\text {wet }}$ & 1.95 & $\mathrm{~kg} \mathrm{~L}^{-1}$ & Standard soil \\
Organic carbon content & OC & 0.02 & $\mathrm{~g} \mathrm{~g}^{-1}$ & {$[2]$} \\
Soil pore water & $W_{S}$ & 0.35 & $\mathrm{~L} \mathrm{~L} \mathrm{~L}^{-1}$ & Standard soil \\
Soil gas pores & $G_{S}$ & 0.1 & $\mathrm{~L} \mathrm{~L}^{-1}$ & Standard soil \\
Soil dry density & $\rho_{d r y}$ & $=\rho_{\text {wet }}-W_{S}$ & $\mathrm{~kg} \mathrm{~L}^{-1}$ & Standard soil \\
\hline
\end{tabular}


Table 2. Plant parameters, independent of size.

\begin{tabular}{|c|c|c|c|c|}
\hline Parameter & Symbol & Value & Unit & Reference \\
\hline Root water content & $W_{R}$ & 0.89 & $\mathrm{~L} \mathrm{~kg}^{-1}$ & {$[23]$} \\
\hline Root lipid content ${ }^{(1)}$ & $L_{R}$ & 0.025 & $\mathrm{~g} \mathrm{~g}^{-1}$ & [13] \\
\hline Root gas pores & $G_{R}$ & 0.1 & $\mathrm{~L} \mathrm{~kg}^{-1}$ & [13] \\
\hline Growth rate root & $k_{R}$ & 0.1 & $d^{-1}$ & [13] \\
\hline Growth rate stem & $k_{S t}$ & $2.74 \times 10^{-5}$ & $\mathrm{~d}^{-1}$ & [12] \\
\hline Stem water fraction & $W_{S t}$ & 0.38 & $\mathrm{~L} \mathrm{~kg}^{-1}$ & {$[12]$} \\
\hline Stem gas pores & $G_{S t}$ & 0.2 & $\mathrm{~L} \mathrm{~kg}^{-1}$ & {$[12]$} \\
\hline Leaves water content & $W_{L}$ & 0.8 & $\mathrm{~L} \mathrm{~kg}^{-1}$ & [9] \\
\hline Leaves lipid content ${ }^{(1)}$ & $L_{L}$ & 0.02 & $\mathrm{~g} \mathrm{~g}^{-1}$ & [9] \\
\hline Growth rate leaves & $k_{L}$ & 0.035 & $d^{-1}$ & [9] \\
\hline Relative humidity & $r h$ & 0.5 & $(-)$ & generic \\
\hline Temperature & Temp & 20 & ${ }^{\circ} \mathrm{C}$ & generic \\
\hline Apple fruit water & $W_{F}$ & 0.844 & $\mathrm{~L} \mathrm{~kg}^{-1}$ & {$[23]$} \\
\hline \multicolumn{5}{|l|}{ content } \\
\hline Apple fruit air pores & $G_{F}$ & 0.25 & $\mathrm{~L} \mathrm{~kg}^{-1}$ & {$[24]$} \\
\hline Apple fruit lipid & $L_{F}$ & 0.006 & $\mathrm{~g} \mathrm{~g}^{-1}$ & {$[23]$} \\
\hline \multicolumn{5}{|l|}{ content } \\
\hline Growth rate fruits & $k_{F}$ & 0.035 & $d^{-1}$ & see leaves \\
\hline Diffusion length fruits & $x$ & 0.01 & $\mathrm{~m}$ & generic \\
\hline
\end{tabular}

(1) This lipid content includes all lipid-like compounds, not only fat and oil, but also waxes like suberin and cutin. 
Table 3. Size-dependent plant parameters.

\begin{tabular}{lcccc}
\hline Parameter & Symbol & Value & Unit & Reference \\
\hline Transpiration & $Q$ & 0.822 & $\mathrm{~L} \mathrm{~d}^{-1}$ & {$[14]$} \\
Water flow velocity & $u_{W}$ & 40 & $\mathrm{~m} \mathrm{~d}^{-1}$ & {$[18]$} \\
Mass of thick roots & $M_{R}$ & 1 & $\mathrm{~kg}$ & {$[12]$} \\
Radius of thick roots & $R_{R}$ & 0.01 & $\mathrm{~m}$ & generic \\
Stem height & $Z$ & 5 & $\mathrm{~m}$ & generic \\
Stem radius & $R_{S t}$ & 0.1 & $\mathrm{~m}$ & generic \\
Leaf area & $A_{L}$ & 2 & $\mathrm{~m}^{2}$ & {$[9]$ for 0.4 $\mathrm{kg}$} \\
Leaf mass & $M_{L}$ & 0.4 & $\mathrm{~kg}$ & {$[12]$} \\
Fruit radius & $R_{F}$ & 0.04 & $\mathrm{~m}$ & generic \\
Fruit mass & $M_{F}$ & 0.4 & $\mathrm{~kg}$ & same as leaves \\
Bark thickness & $d_{B a r k}$ & 0.01 & $\mathrm{~m}$ & generic \\
\hline
\end{tabular}




\section{Figure Captions}

Figure 1. Average consumption data of Bavarians, age class 25 - 50 years [3], tap water [2]; "Cola" refers to all softdrinks with caffeine.

Figure 2. Model structure.

Figure 3. Chemical space ( $\mathrm{x}$-axis $\log \mathrm{K}_{\mathrm{OW}}$ and $\mathrm{y}$-axis $\log \mathrm{K}_{\mathrm{AW}}$ ) plotted versus calculated concentrations $(\mathrm{mg} / \mathrm{kg})$ in top stem (a), leaves (b) and fruits (c); input scenario: $\mathrm{C}_{\text {Soil } 1}=$ $1 \mathrm{mg} \mathrm{kg}{ }^{-1}$.

Figure 4. Chemical space (x-axis $\log \mathrm{K}_{\mathrm{AW}}$ and $\mathrm{y}$-axis $\log \mathrm{K}_{\mathrm{OW}}$ ) plotted versus calculated concentrations $(\mathrm{mg} / \mathrm{kg})$ in top stem (a), leaves (b) and fruits (c); input scenario: $\mathrm{C}_{\mathrm{Air}}=1$ $\mu \mathrm{g} \mathrm{m}^{-3}$.

Figure 5. Travel time (days) from the bottom to the top of the stem for compounds with varying $\log \mathrm{K}_{\mathrm{OW}}$

Figure 6. Chemical space ( $\mathrm{x}$-axis $\log \mathrm{K}_{\mathrm{OW}}$ and $\mathrm{y}$-axis $\log \mathrm{K}_{\mathrm{AW}}$ ) plotted versus half-time for loss from stem (days).

Figure 7. Transpiration stream concentration factor TSCF $\left(\mathrm{C}_{\mathrm{Xy} 2} / \mathrm{C}_{\mathrm{W}}\right)$ calculated by the model with/out fine roots compared to the regression of Briggs et al. [15]. 


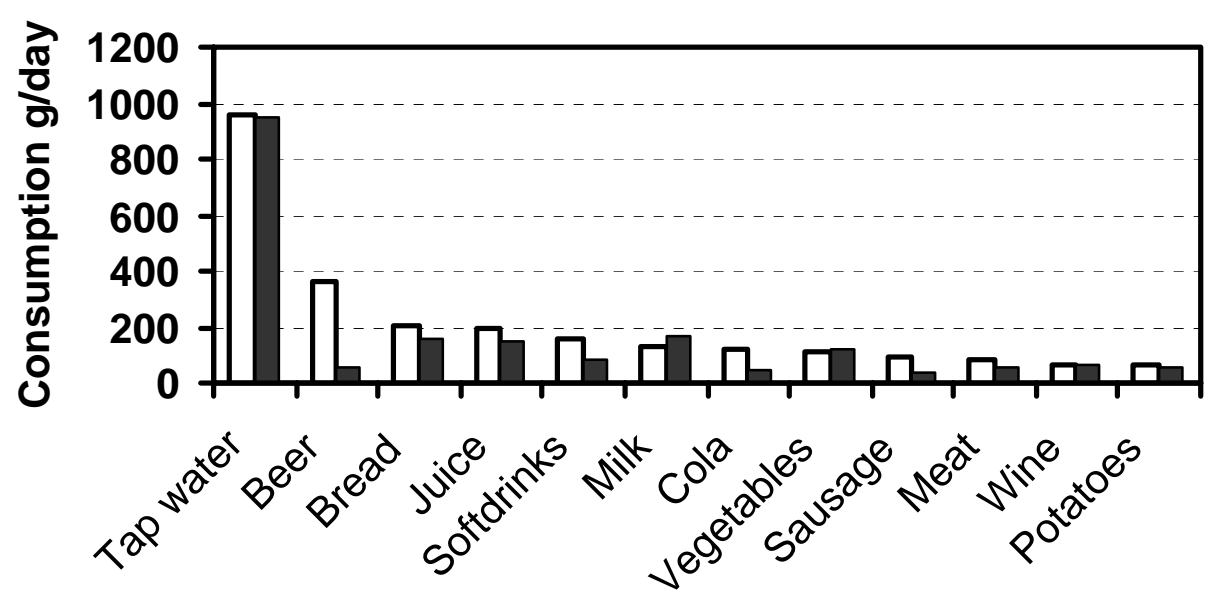

$\square$ Male $\square$ Female

Trapp Figure 1 


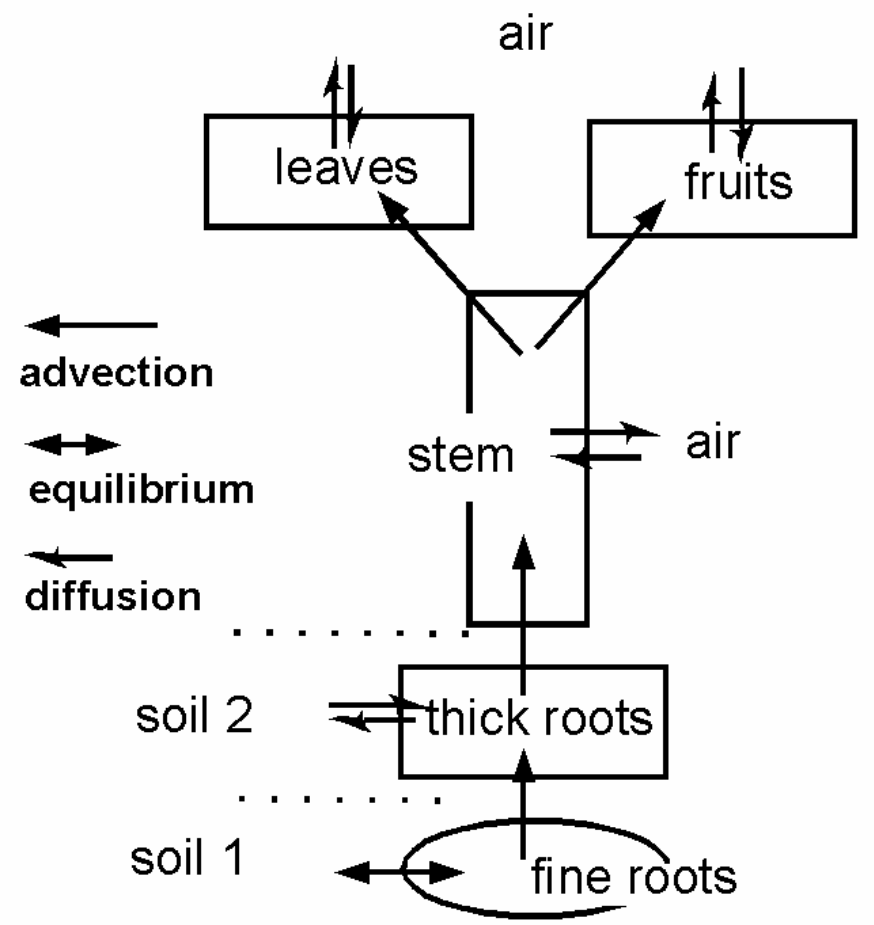

Trapp Figure 2 

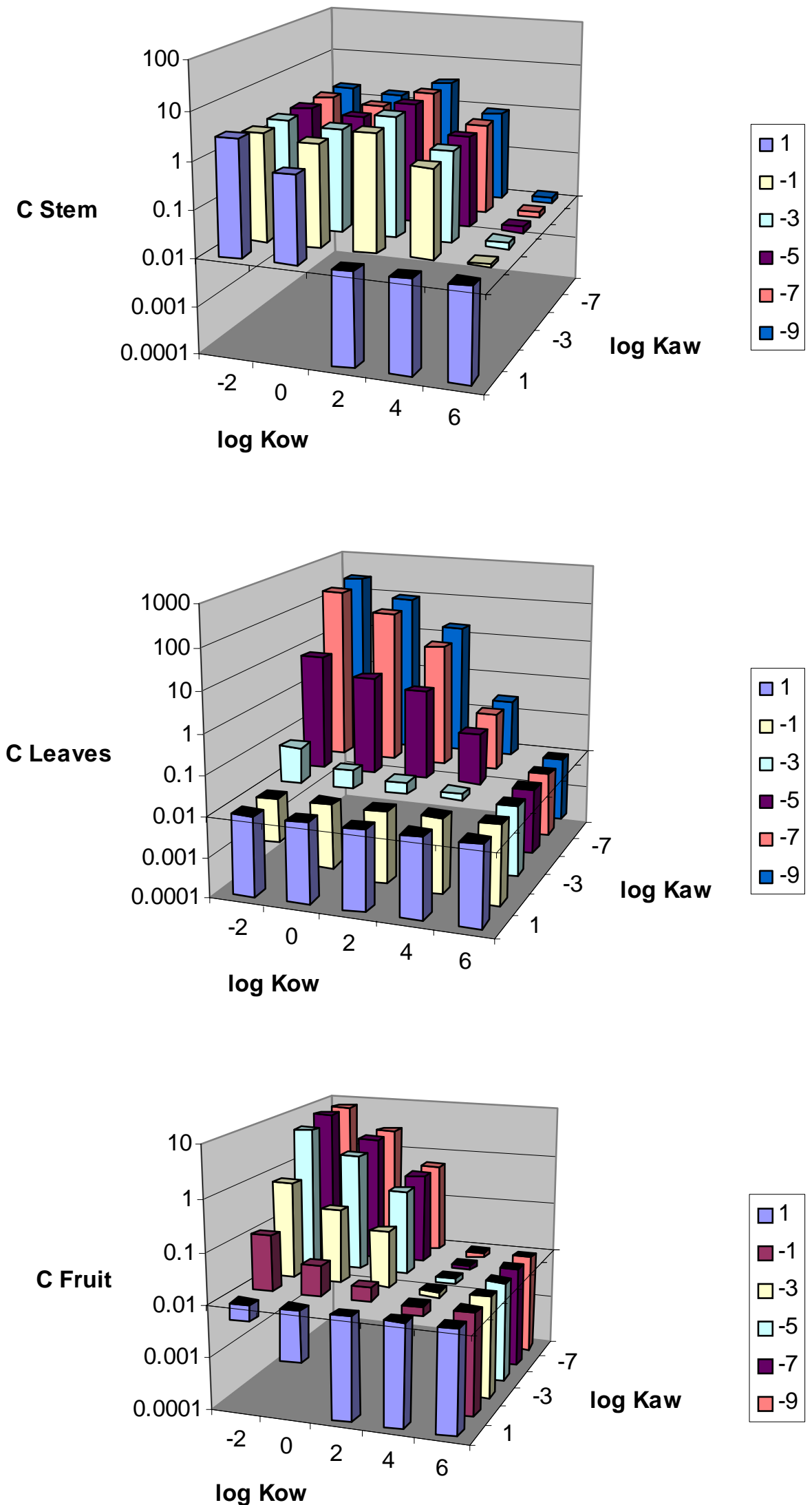

Trapp Figure 3 a b c 

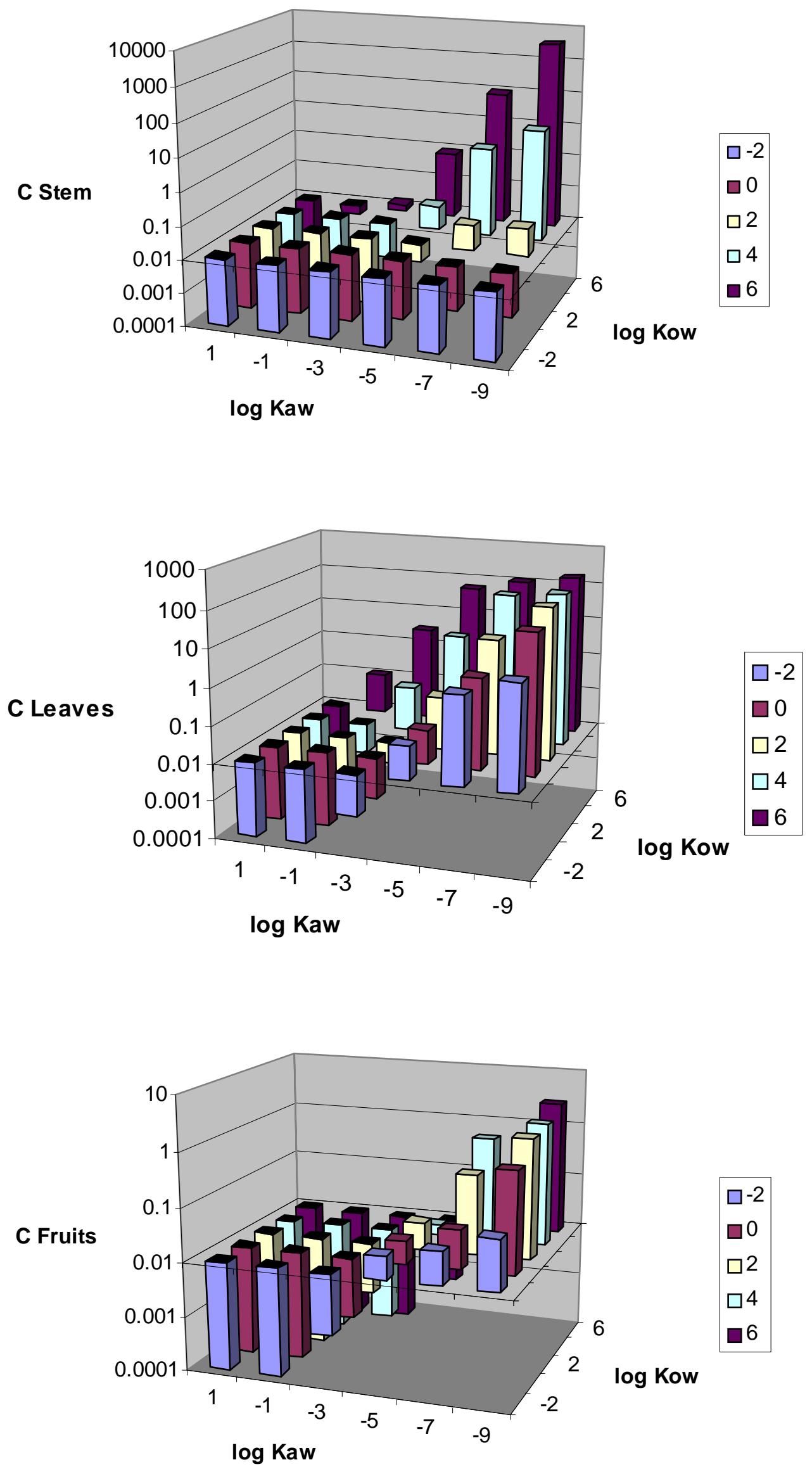

Trapp Figure 4 a b c 


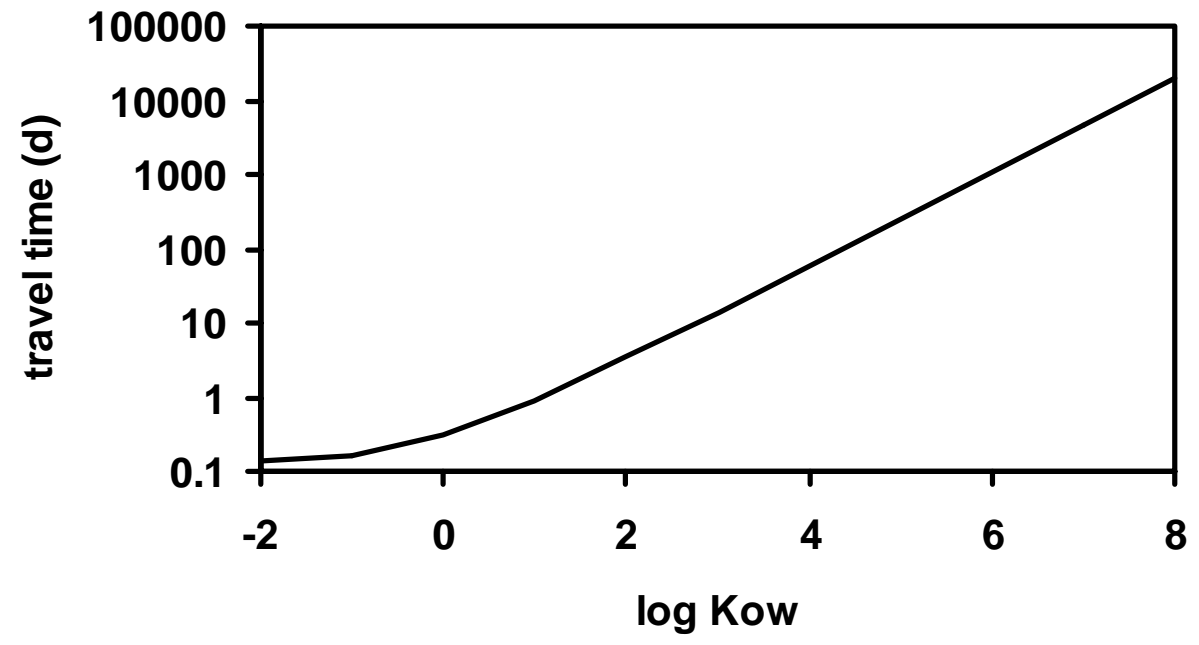

Trapp Figure 5 


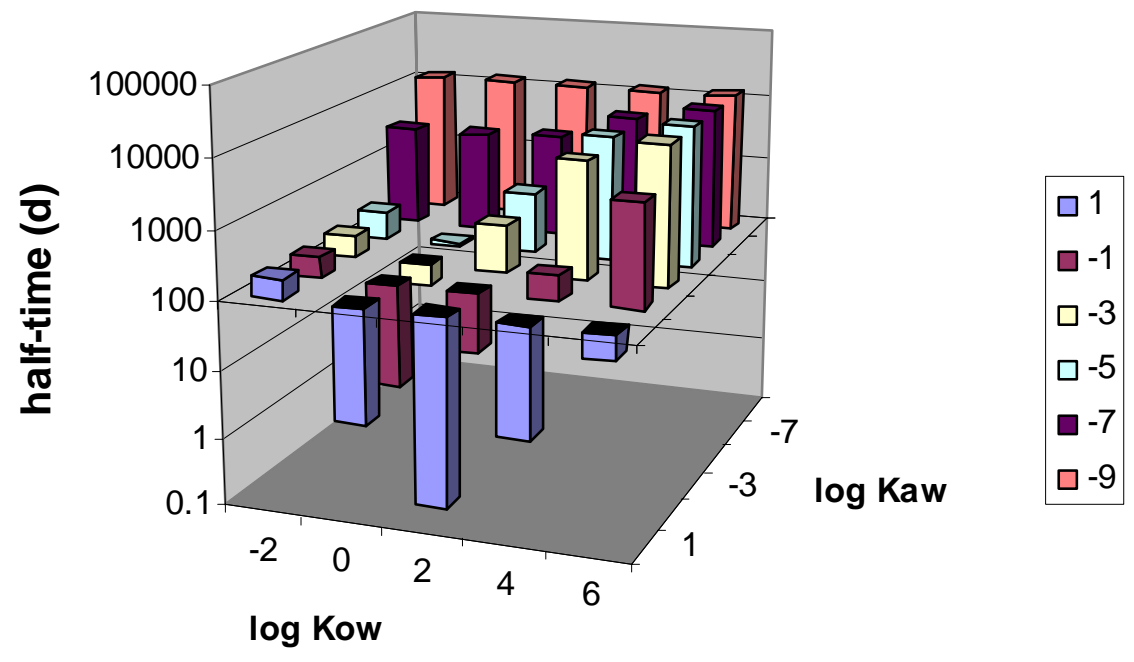

Trapp Figure 6 


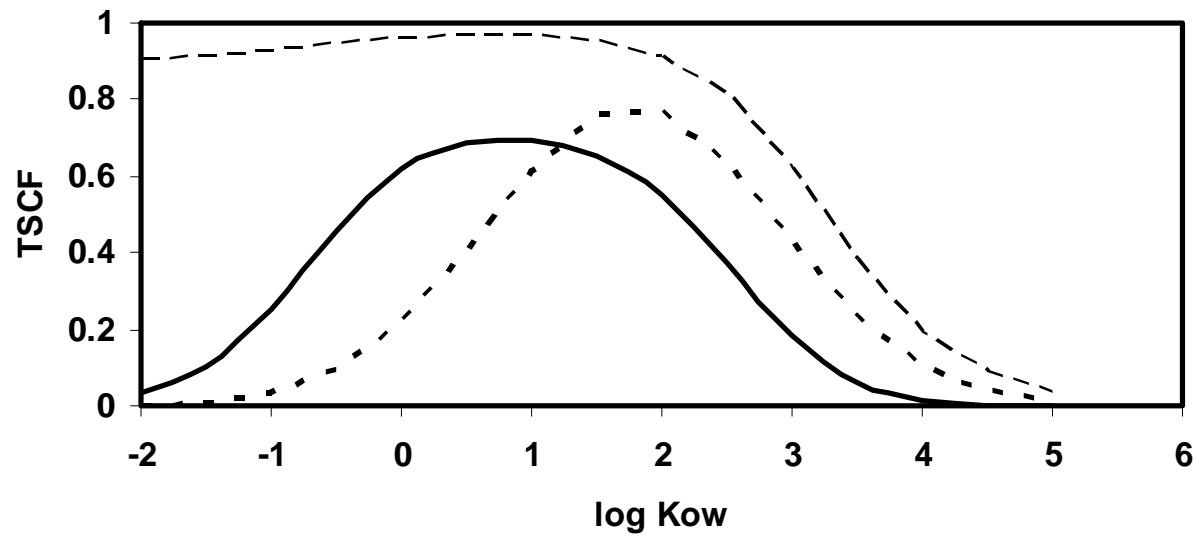

model thick roots only ---- with fine roots - - - Briggs regression

Trapp Figure 7 